\title{
Ancient water bottle use and polycyclic aromatic hydrocarbon (PAH) exposure among California Indians: a prehistoric health risk assessment
}

\author{
Sabrina B. Sholts ${ }^{1}$, Kevin Smith², Cecilia Wallin³ ${ }^{3}$ Trifa M. Ahmed ${ }^{4}$ and Sebastian K. T. S. Wärmländer ${ }^{3,5^{*}}$ (D)
}

\begin{abstract}
Background: Polycyclic aromatic hydrocarbons (PAHs) are the main toxic compounds in natural bitumen, a fossil material used by modern and ancient societies around the world. The adverse health effects of PAHs on modern humans are well established, but their health impacts on past populations are unclear. It has previously been suggested that a prehistoric health decline among the native people living on the California Channel Islands may have been related to PAH exposure. Here, we assess the potential health risks of PAH exposure from the use and manufacture of bitumen-coated water bottles by ancient California Indian societies.

Methods: We replicated prehistoric bitumen-coated water bottles with traditional materials and techniques of California Indians, based on ethnographic and archaeological evidence. In order to estimate PAH exposure related to water bottle manufacture and use, we conducted controlled experiments to measure PAH contamination 1) in air during the manufacturing process and 2) in water and olive oil stored in a completed bottle for varying periods of time. Samples were analyzed with gas chromatography/mass spectrometry (GC/MS) for concentrations of the 16 PAHs identified by the US Environmental Protection Agency (EPA) as priority pollutants.
\end{abstract}

Results: Eight PAHs were detected in concentrations of $1-10 \mathrm{\mu g} / \mathrm{m}^{3}$ in air during bottle production and 50-900 ng/L in water after 2 months of storage, ranging from two-ring (naphthalene and methylnaphthalene) to four-ring (fluoranthene) molecules. All 16 PAHs analyzed were detected in olive oil after 2 days (2 to $35 \mu \mathrm{g} / \mathrm{kg}$ ), 2 weeks ( 3 to $66 \mu \mathrm{g} / \mathrm{kg}$ ), and 2 months (5 to $140 \mu \mathrm{g} / \mathrm{kg}$ ) of storage.

Conclusions: For ancient California Indians, water stored in bitumen-coated water bottles was not a significant source of PAH exposure, but production of such bottles could have resulted in harmful airborne PAH exposure.

Keywords: PAH, Naphthalene, Bitumen, Asphaltum, Public health, Environmental exposure, Ancient technology

\section{Background}

Throughout human history, polycyclic aromatic hydrocarbons (PAHs) have been an ever-present health hazard. Consisting of two or more condensed aromatic benzene rings and occurring in a large number of isomers, the lipophilic PAHs are readily taken up by the human body and distributed to different body systems

\footnotetext{
* Correspondence: seb@dbb.su.se

${ }^{3}$ Department of Biochemistry and Biophysics, Stockholm University, S-106 91 Stockholm, Sweden

${ }^{5}$ UCLA/Getty Conservation Programme, Cotsen Institute of Archaeology,

UCLA, Los Angeles, California, USA

Full list of author information is available at the end of the article
}

and tissues, including the fetus via maternal exposure [1]. Significant health problems associated with high and/or chronic levels of PAH exposure, which may vary between populations and groups [2,3], include cancer, altered hormone levels, damage to internal organs, deficiencies in important nutrients such as vitamin A, reproductive and developmental impairments, and possibly neurodegeneration [4-13]. Given these deleterious effects, recently it has been suggested that increased tolerance of PAH exposure was an early human adaptation, providing an evolutionary advantage over other hominin species [14]. 
In modern human societies, the main sources of PAH exposure are related to fossil fuel processing, gasoline and diesel combustion, road paving, roofing, food processing, and tobacco smoking, as well as occasional extraordinary events such as major oil spills and wildfires [15]. In some regions biomass burning for space heating during winter is a key source of $\mathrm{PAH}$ exposure $[16,17]$. In the ancient world PAH sources were fewer: hydrocarbons could be generated by burning organic materials, or encountered in the form of fossil bitumen (also known as asphaltum or petroleum) formed over millions of years by anaerobic decomposition of dead organisms. In world regions such as California, Mexico, and the Near East, bitumen spontaneously seeps to the Earth's surface from certain geological formations, where people for at least 70,000 years have been collecting and using bitumen for a range of purposes, due to its adhesive, water-repellent, and decorative properties [18-24].

Bitumen is among the best evidence for exposure to persistent organic pollutants (POPs) in past human populations, given its excellent preservation in the archaeological record. Adverse effects of PAH exposure can sometimes manifest directly in the skeleton as e.g. poor bone quality [25], gross abnormalities [26], or reduced stature [9], but the actual exposure levels are generally unknown. Unlike heavy metals such as lead, which readily bioaccumulate in bone [27], PAHs are typically metabolized and eliminated from the human body within days of uptake [28]. As PAH concentrations in bone or hair do not reflect chronic exposure levels, the dose and timing of PAH exposure throughout life must therefore be estimated indirectly through other means. Earlier approaches to this problem include estimating daily doses of PAHs from traditional smoked foods [29], and presenting an exposure scenario for health risk assessment of a range of traditional native American activities and resources [30].

We previously suggested that $\mathrm{PAH}$ exposure from increased use of bitumen may have contributed to a prehistoric health decline of the Chumash Indians of the Santa Barbara Channel region [31], evident in ancient skeletal remains showing reduced stature, increased frequencies in dental defects of linear enamel hypoplasias, and skeletal lesions of porotic hyperostosis during the Late Holocene [32-40]. While these conditions are non-specific indicators of stress, early life exposure to PAHs has been linked with fetal growth disruption and anemia [10, 41-45], i.e. potential causes or factors of reduced skeletal size and porotic hyperostosis [46, 47]. In the Santa Barbara Channel, bitumen continuously seeps into the water from natural submarine sources, contributing to PAH exposure linked to size reduction and tissue abnormalities in local marine organisms $[48,49]$.
Bitumen was used for a variety of purposes by the Chumash and other native Californians, such as sealant for containers and watercraft, glue for fixing arrowheads and spear points to shafts, decoration on textiles and skin, an ingredient in ritual practices and medicinal remedies, chewing gum, and smoke-generating material for signaling [31, 50-54]. On the California Channel Islands, bitumen has been found in cultural strata between 10,000 and 7500 years old [55] and in baskets around 5000 years old [56]. For year-round inhabitants, population growth and extended droughts made bitumencoated baskets crucial for storing limited supplies of drinking water, as pottery was not used on the islands during prehistoric times [57]. Over the subsequent millennia, the invention of the bitumen-sealed plank canoe (tomol) facilitated wide-ranging pelagic fishing as well as cross-channel transportation of both people and trade goods such as bitumen [57-59]. However, the potential levels of PAH exposure resulting from these cultural uses of bitumen have so far not been investigated [31].

In this study, we employed experimental archaeological methods to assess the health risks related to PAH exposure from the manufacture and use of bitumencoated water bottles. We first used traditional materials and techniques to create water bottle replicas, based on ethnographic, ethnohistoric, and archaeological evidence. We then measured PAH concentrations in air during the manufacturing process, and in water and olive oil stored in one of the vessels for varying periods of time. Gas chromatography/mass spectrometry (GC/ MS) was used to determine in all samples the concentrations of the 16 priority PAHs identified by the United States Environmental Protection Agency (EPA). The results were assessed in relation to recommended exposure levels for modern populations, and previous knowledge about health, diet, and technology in native Californian societies.

\section{Methods \\ Water bottle replication}

Two replicate water bottles (Fig. 1 and Additional file 1: Figure S1) were produced following procedures outlined in ethnohistoric accounts, and supported by archaeological finds. These replicas were manufactured in a style similar to basketry bottles from coastal and insular southern California, such as a small specimen found in the Cuyama drainage system in the Sierra Madre Mountains [60]. Using a Monterey chert flake and a bird bone awl as tools, the basketry frameworks were woven from Juncus sp. rush collected in coastal northern California, a plant previously attributed to water bottle basketry production in southern California $([60,61]: 167,204)$. 


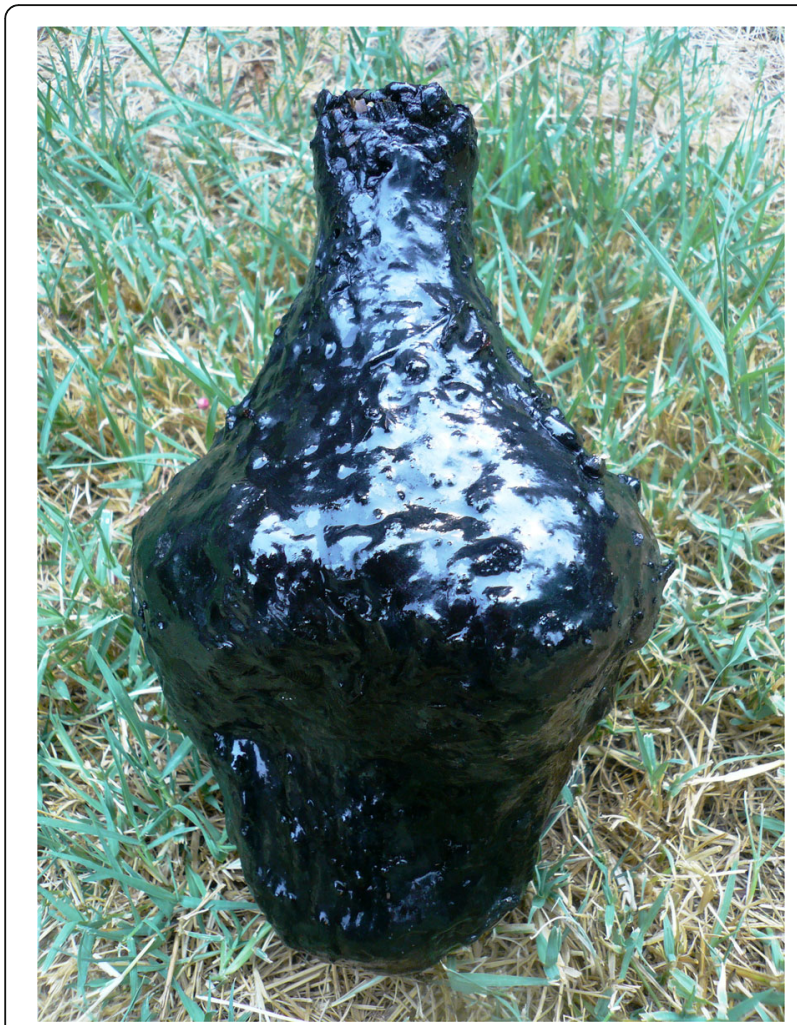

Fig. 1 A completed water basket-bottle coated with a mixture of pitch and bitumen (yop), in which water and olive oil were stored for liquid PAH analysis

The procedure for coating the twined basketry with bitumen followed ethnohistoric accounts of the Lone Woman of San Nicolas Island [62], as well as data generated from archaeological assemblages from the region $[51,56,63]$. Choosing the appropriate material(s) was however not trivial. In the Late Period (AD 1150-1782) bitumen had become a staple commodity among the Chumash, with cakes of the material "always kept on hand for immediate use" [64] and traded all along the channel shores ([65]:51-52). Different forms of the material existed. According to the ethnographic accounts collected by John P. Harrington, the historic Chumash differentiated between hard bitumen mined from land deposits (woqo) and soft bitumen washed ashore from submarine seeps (malak) ([65]:51-52). Only the hard bitumen was deemed good enough to be used when constructing the tomol plank canoe. Chunks of hard bitumen were then broken up with pounding stones, mixed with pine pitch and sometimes with red ochre, and boiled until the substance reached proper consistency [65]. Three different mixtures were used: the yop, with a larger proportion of bitumen than pitch, was used to glue the planks together; adding additional pitch to the yop produced a waxy substance used to waterproof the milkweed fibers that tied the planks together; and adding red ochre to the yop produced the mixture used as paint sealant [65]. As we did not know whether the woqo-bitumen or the malak-bitumen would be more appropriate to use for basket-coating, we made two baskets with one of each material.

For the first bottle, patches of float bitumen (malak) collected from the coast of San Nicolas Island in the southern California Channel Islands were used. In line with archaeological evidence $[52,63,66]$, an abalone (Haliotis rufescens) shell was used as a mixing dish, and the malak was indirectly heated with tarring pebbles (Additional file 1: Figure S1 and Figure S2). These small (20-40 mm) meta-volcanic pebbles, which are virtually identical to the bitumen-coated heating stones (tarring pebbles) found in archaeological assemblages throughout the Channel Islands $[56,66]$, were gathered from a conglomerate outcrop on San Nicolas Island adjacent to the archaeological site of CA-SNI-40. The malak was then put in the base of a basketry framework, and hot tarring pebbles were added to melt the malak. After 1 minute, the basket was lifted with both hands and swirled rapidly in a rotary motion, generating centrifugal force that allowed the pebbles to push the malak into the basket weave. The process was repeated six times, after which the malak effectively coated the interior vessel surface. The exterior surface was coated with malak that was first heated with tarring pebbles in the shell dish and then applied using a beveled sea mammal bone and a piece of hard wood as tools (Additional file 1: Figure S3). After the entire bottle had been coated with malak, it was slowly rotated over an open flame to re-melt the malak on the outer surface, thereby creating a smooth exterior as well as sealing potential leaks (Additional file 1: Figure S1).

For the second bottle, hard bitumen (woqo) was collected from a mainland seep ("quarry") in Goleta on the Santa Barbara coast. This site was previously an important source of bitumen for indigenous southern California groups [63]. Large chunks of solid bitumen were crushed using a hammer and anvil technique relying on two sandstone beach cobbles (Additional file 1: Figure S2). However, when this woqo was pulverized, it would not melt from direct heating (open flame) nor from indirect heating (hot tarring pebbles). Ethnographically, it has been noted that "high quality" mainland bitumen was mixed with conifer resin (pitch) and subsequently traded or used for gluing purposes [63]. Guided by ethnohistoric descriptions [65] and trial-anderror, we prepared a mixture consisting of roughly 55\% woqo and $45 \%$ conifer resin from a local Pinus radiata species (Additional file 1: Figure S1). That is, we arrived at the mixture known to the Chumash Indians as yop. Our yop had a consistency similar to that of the malak, and it was applied to the basketry framework in the same way. 
For the current PAH measurements, it has previously been shown that the water-soluble fraction of hydrocarbons has been washed away in malak/float bitumen $[31,67]$. As PAH levels consequently should be higher for liquids stored in the yop-coated bottle, this vessel was selected for the water/oil storage experiments described below.

\section{Air analysis}

Following standard methods developed by the US EPA in 1999, sorbent Poly-Urethane Foam (PUF) cartridges were obtained from Test America (Sacramento, California) and operated with a Gilian GilAir-5 air sampling pump from PINE Environmental (San Leandro, California). These pumps require a pre-calibration of between 1 and $5 \mathrm{~L} / \mathrm{min}$, so the pump used in this component of the study was arbitrarily set to take in air at a $3 \mathrm{~L} / \mathrm{min}$ rate throughout a 30 min sample window. The pump was placed approximately $1 \mathrm{~m}$ from the bitumen processing area during coating of the basketry water bottle framework. The GC/MS analysis of both experimental and control (blank) samples at the TestAmerica laboratory revealed that under these experimental conditions none of the 16 targeted PAHs exceeded concentrations above the detection limits.

In a follow-up experiment, we increased the flow rate of the PUF sampler to $5 \mathrm{~L} / \mathrm{min}$ (i.e. the upper limit of the pump pre-calibration) and extended the sampling period to 1 hour. Although an air flow of $7-9 \mathrm{~L} / \mathrm{min}$ would be more consistent with human respiration during sedentary activities, the measured PAH concentrations (in $\mu \mathrm{g} / \mathrm{m}^{3}$ ) do not depend on the air flow during sampling, and a higher air flow may run the risk of "breakthrough" where the sample media become saturated and no longer retain all pollutants collected during sampling. As shown below, the upper pre-calibration limit of $5 \mathrm{~L} / \mathrm{min}$ was enough to obtain accurate concentrations for a number of PAHs. In this experimental setup we exclusively sampled the surrounding air during the process of mixing pulverized quarry bitumen and conifer resin, using the materials and techniques described above. In total, $522 \mathrm{~g}$ of bitumen and $422 \mathrm{~g}$ of conifer resin were pulverized, mixed, and heated with tarring pebbles in an abalone shell. Over the one-hour sampling period, tarring pebbles were alternated from the driftwood fire into the abalone mixing dish to keep the yop in a viscous state. As the experiment was conducted outdoors and a slight wind was prevailing from southwest to northeast, a $50 \mathrm{~cm}$ high windbreak was constructed around the bitumen processing area. For the initial 10 min of sampling, the PUF media were fixed to the wall of the windbreak and secured $40 \mathrm{~cm}$ above the mixing dish. During the subsequent $50 \mathrm{~min}$ sampling interval, the PUF media were secured approximately
$10 \mathrm{~cm}$ above the bitumen mixing dish to ensure adequate samples of tar/pitch vapors (Additional file 1: Figure S2). Upon completion of the 1 hour field sample, the PUF media were sealed in sterile aluminum foil within an air-tight container, placed on ice to cool to around $4^{\circ}$ $\mathrm{C}$ with no post-sampling exposure to light, and transported within the hour to the TestAmerica laboratory for GC/MS analysis.

\section{Liquids analysis}

To measure PAH concentrations in liquids stored in the bitumen-coated water bottle, controlled experiments with olive oil and distilled water were carried out at Stockholm University, Sweden. The replicate bottle was first filled with double-distilled water $\left(\mathrm{ddH}_{2} \mathrm{O}\right)$, which was allowed to sit in the bottle without stirring or other agitation at room temperature for a period of 2 months and then removed for analysis. The bottle was then re-filled with commercial olive oil obtained at a local super market and stored at room temperature without agitation (Additional file 1: Figure S3). Samples of the olive oil were collected after 2 days, 2 weeks, and 2 months. The water and olive oil samples were analyzed with GC/MS for the 16 EPA priority PAHs in the $\mu \mathrm{g} / \mathrm{L}-\mathrm{ng} / \mathrm{L}$ range at ALS Scandinavia (Stockholm, Sweden).

\section{Results}

For the air samples recorded during bottle manufacture, seven priority PAHs were detected in concentrations around 1-4 $\mu \mathrm{g} / \mathrm{m}^{3}$ (Table 1). The PAHs encountered ranged from two-ring (naphthalene and methylnaphthalene) to four-ring molecules (fluoranthene). For the water sample, similar molecules were found. After 2 months of incubation in the bottle, PAHs in the size range of naphthalene to fluoranthene had accumulated in the water in concentrations of $0.05-0.9 \mu \mathrm{g} / \mathrm{L}$. Also some aliphatic hydrocarbons of sizes $\mathrm{C}_{16}-\mathrm{C}_{35}$ were detected (Table 1). The most abundant PAHs in the water were naphthalene, phenanthrene, and acenaphthalene, while in the air sample naphthalene, phenanthrene, and 2-methylnaphthalene showed the highest concentrations. For the olive oil stored in the bottle, all 16 PAHs tested for were encountered in concentrations above the detection limits. The concentrations of these PAHs increased over time: after 2 days of storage the PAH levels ranged from 2 to $35 \mu \mathrm{g} / \mathrm{kg}$, while they ranged from 3 to $66 \mu \mathrm{g} /$ $\mathrm{kg}$ after 2 weeks, and from 5 to $140 \mu \mathrm{g} / \mathrm{kg}$ after 2 months (Table 1). As in the water sample, the most abundant PAHs in the olive oil were two- and three-ring PAHs such as naphthalene, phenanthrene, and fluorene. The concentrations of larger four- to six-ring PAHs were an order of magnitude lower. Some PAHs were already present in the commercial olive oil before it was poured 
Table 1 Concentrations of individual PAHs in the air, water, and olive oil samples analyzed in this study

\begin{tabular}{|c|c|c|c|c|c|c|}
\hline \multirow[t]{2}{*}{ Compound } & \multirow{2}{*}{$\begin{array}{l}\text { Air }\left(\mu \mathrm{g} / \mathrm{m}^{3}\right) \\
1 \mathrm{~h}\end{array}$} & \multirow{2}{*}{$\begin{array}{l}\text { Water (ng/L) } \\
2 \text { months }\end{array}$} & \multicolumn{4}{|c|}{ Olive oil $(\mu \mathrm{g} / \mathrm{kg})$} \\
\hline & & & blank & 2 days & 2 weeks & 2 months \\
\hline Acenaphthene & 1.7 & $37 \pm 11$ & $<0.93$ & 1.6 & 4.6 & 7.9 \\
\hline Acenaphthylene & 1.3 & $873 \pm 262$ & $<1.6$ & 20 & 45 & 77 \\
\hline Anthracene & 0.72 & $49 \pm 15$ & 3.4 & 9.4 & 9.8 & 25 \\
\hline Benzo[a]anthracene & $<0.67$ & $<0.010$ & 2.4 & 6.3 & 6.6 & 12 \\
\hline Benzo[a]pyrene & $<0.67$ & $<0.010$ & $<0.28$ & 4.4 & 3 & 8 \\
\hline Benzo[b]fluoranthene & $<0.67$ & $<0.010$ & $<0.6$ & 3 & 4 & 7.8 \\
\hline Benzo[g,h,i]perylene & $<0.67$ & $<0.010$ & $<0.47$ & 2.2 & 3 & 16 \\
\hline Benzo[k]fluoranthene & $<0.67$ & $<0.010$ & $<0.5$ & 2 & 2.4 & 5.3 \\
\hline Chrysene & $<0.67$ & $<0.010$ & $<0.79$ & 3.2 & 7.9 & 13 \\
\hline Dibenzo[a,h]anthracene & $<0.67$ & $<0.010$ & $<0.34$ & 1.6 & $<0.79$ & $<0.73$ \\
\hline Fluoranthene & 1.6 & $74 \pm 22$ & $<2.3$ & 16 & 26 & 36 \\
\hline Fluorene & 1.7 & $124 \pm 37$ & $<2.6$ & 15 & 37 & 140 \\
\hline Indeno[1,2,3-cd]pyrene & $<0.67$ & $<0.010$ & $<0.031$ & $<0.47$ & $<0.66$ & 5.7 \\
\hline Naphthalene & 4.4 & $206 \pm 62$ & $<12$ & 21 & 31 & 67 \\
\hline Phenanthrene & 4.2 & $281 \pm 84$ & 13 & 35 & 66 & 80 \\
\hline Pyrene & $<0.67$ & $70 \pm 21$ & 2.3 & 21 & 37 & 71 \\
\hline 2-Methylnaphthalene ${ }^{a}$ & 9.2 & $\mathrm{n} / \mathrm{a}$ & $\mathrm{n} / \mathrm{a}$ & $\mathrm{n} / \mathrm{a}$ & $\mathrm{n} / \mathrm{a}$ & $\mathrm{n} / \mathrm{a}$ \\
\hline Aliphatic C16-C35 & $\mathrm{n} / \mathrm{a}$ & $13 \pm 4$ & $\mathrm{n} / \mathrm{a}$ & $\mathrm{n} / \mathrm{a}$ & $\mathrm{n} / \mathrm{a}$ & $\mathrm{n} / \mathrm{a}$ \\
\hline
\end{tabular}

${ }^{a}$ Not one of the 16 priority PAHs identified by the United States Environmental Protection Agency (EPA)

into the vessel, most notably phenanthrene $(13 \mu \mathrm{g} / \mathrm{kg})$, which raises questions about the quality of the product.

\section{Discussion}

In the global environment at least 100 different known PAHs are widespread, with typical properties such as low volatility at room temperature, poor solubility in water, and high lipophilicity. These characteristics become more pronounced with increasing molecular weight, which is accompanied by increased melting/ boiling points, increased lipophilicity, decreased aqueous solubility, decreased vapor pressure, and increased resistance to oxidation and reduction (Additional file 1: Table S1). In assessing the toxic potential of an environmental sample, the 16 EPA PAHs are often used to represent all PAHs and evaluated as a sum, although other PAHs of considerably higher toxicity have been identified in the decades since the list was established [68]. The main advantage to using the 16 EPA PAHs in this study is their comparability and analytical consistency with a wide range of datasets and studies from the last several decades.

Although they are usually discussed as a group, PAHs of different molecular weight vary substantially in their behavior and distribution in the environment and the human body. Some individual PAHs, such as those detected at particularly high levels in the present study, have been linked specifically to certain effects and adverse outcomes. Most air concentration data for individual PAHs focus on the five-ring compound benzo(a)pyrene $(\mathrm{B}[\mathrm{a}] \mathrm{P})$, which is one of the most toxic PAHs known and widely used in epidemiological studies as an indicator for PAH exposure ([69]:xx-xxi). Given that $\mathrm{B}[\mathrm{a}] \mathrm{P}$ was not detected among the $44 \mathrm{PAHs}$ that we previously identified in bitumen from the California Channel Islands region [31], it is not surprising that $\mathrm{B}[\mathrm{a}] \mathrm{P}$ was also not detected in this study. Instead, the smallest and most soluble compounds (e.g., acenaphthene, fluorene, naphthalene, and phenanthrene) showed the highest concentrations in all the experimental samples (Table 1). These compounds have been assessed for toxicity relative to $\mathrm{B}[\mathrm{a}] \mathrm{P}$, and have been assigned low toxic equivalency factors (TEFs, also known as Relative Potency Factors or RPFs) in the order of 0.001 (Additional file 1: Table S1). Using these factors, the potency of a PAH mixture can be calculated in terms of $\mathrm{B}[\mathrm{a}] \mathrm{P}$ potency equivalence $(\mathrm{B}[\mathrm{a}] \mathrm{P} \mathrm{PEQ})$ by the relative potency approach [70]. Each PAH concentration is then multiplied by its TEF (or RPF) factor (Additional file 1: Table S1), the contributions of each PAH are added, and the sum is the $\mathrm{B}[\mathrm{a}] \mathrm{P}$ potency equivalence which is to be compared to the EPA's B[a]P reference values [70].

Of the detected PAHs only naphthalene - the simplest $\mathrm{PAH}$, consisting of two fused benzene rings - has been given both an oral reference dose (RfD) and an inhalation reference concentration (RfC) in EPA's 
Integrated Risk Information System (IRIS) (Additional file 1: Table S1). Naphthalene was furthermore one of the PAHs detected in high concentrations in all of the air, water, and oil samples. As it would be too lengthy to discuss in detail the health effects of all detected PAHs, we here focus the discussion on total PAH mixture toxicity in terms of $\mathrm{B}[\mathrm{a}] \mathrm{P}$ potency equivalence and on naphthalene as a model PAH. Naphthalene is readily absorbed by humans and other animals via inhalation, dermal contact, and oral ingestion [71]. The inhalation $\mathrm{RfC}$ for naphthalene is $3 \times 10^{-3} \mathrm{mg} / \mathrm{m}^{3}$, calculated by the EPA based on a lowest-observed-adverse-effectlevel (LOAEL) of $10 \mathrm{ppm}$ (human equivalent concentration $=9.3 \mathrm{mg} / \mathrm{m}^{3}$ ) for nasal lesions in mice exposed by inhalation for 2 years [72]. The oral exposure RfD is $2 \times 10^{-2} \mathrm{mg} / \mathrm{kg}^{*}$ day (Additional file 1: Table S1), based on a no-observed-adverse-effect-level (NOAEL) of $100 \mathrm{mg} / \mathrm{kg} /$ day for the absence of decreased mean terminal body weight in male rats exposed by gavage for 13 weeks [72].

Air sampled while preparing yop for water bottle manufacture showed a moderate naphthalene concentration, i.e. $4.4 \mu \mathrm{g} / \mathrm{m}^{3}$ measured $10-40 \mathrm{~cm}$ from the melting bitumen. This is slightly higher than the EPA's inhalation $\mathrm{RfC}$ of $3 \mu \mathrm{g} / \mathrm{m}^{3}$, i.e. the concentration of naphthalene that one supposedly can breathe every day for a lifetime that is not anticipated to cause harmful noncancer health effects. As a comparison, modern cigarette smoke measured a few meters from the cigarette contains about $2.7 \mu \mathrm{g} / \mathrm{m}^{3}$ of naphthalene [73], i.e. somewhat less than the bitumen smoke. As the PAHs in cigarette smoke are produced via pyrolysis, similar PAH levels would have been produced when native Californians smoked tobacco [74]. The $\mathrm{B}[\mathrm{a}] \mathrm{P}$ potency equivalence of the air sample is $140 \mathrm{ng} / \mathrm{m}^{3}$, which is much higher than EPA's inhalation RfC of $2 \mathrm{ng} / \mathrm{m}^{3}$. The main contribution to the high $\mathrm{B}[\mathrm{a}] \mathrm{P}$ PEQ is from fluoranthene (Table 1). Given that the experimental air sample was collected very close to the melting bitumen, few individuals would have experienced such high inhalation exposure levels, at least if the bitumen was processed in an open area. Still, it cannot be ruled out that individuals who regularly worked with melted bitumen could have experienced harmful airborne PAH exposure.

Drinking water stored in the water bottle did not reach significantly high levels of PAH contamination. After 2 months of storage, the measured naphthalene concentration of $0.2 \mu \mathrm{g} / \mathrm{L}$ is considerably lower than the median concentration found in modern US public water systems $(1 \mu \mathrm{g} / \mathrm{L})$ [43]. Using the formula $\mathrm{D}=(\mathrm{C} \times \mathrm{IR} \times \mathrm{EF}) / \mathrm{BW}$, where $\mathrm{D}=$ exposure dose $(\mathrm{mg} / \mathrm{kg}$ *day), $\mathrm{C}=$ contaminant concentration $(\mathrm{mg} / \mathrm{L}), \mathrm{IR}=$ intake rate of contaminated water (L/day), $\mathrm{EF}=$ exposure factor (unitless), and $\mathrm{BW}=$ body weight $(\mathrm{kg})$, the estimated exposure dose of naphthalene via drinking water ingestion for a $70 \mathrm{~kg}$ adult is $\mathrm{D}=(0.0002 \mathrm{mg} / \mathrm{L} \times 3 \mathrm{~L} /$ day $\times 1) / 70 \mathrm{~kg}=8.6 \times 10^{-6} \mathrm{mg} /$ $\mathrm{kg}$ "day. Assuming that water accounted for the total fluid intake of Channel Islanders, and following the recommendation for traditional tribal communities of $3 \mathrm{~L} /$ day for intake rate [30], this estimate is nonetheless far below the EPA's oral RfD for naphthalene of $2 \times 10^{-2} \mathrm{mg} /$ $\mathrm{kg}^{*}$ day. Using the relative potency approach provides a $\mathrm{B}$ [a]P PEQ of $7.5 \mathrm{ng} / \mathrm{L}$ in the water, again with fluoranthene contributing most of the toxicity. Making the same assumptions as above produces an oral intake of $0.32 \mathrm{ng} /$ $\mathrm{kg}^{*}$ day of B[a]P PEQ, which is far less than EPA's oral RfD for $\mathrm{B}[\mathrm{a}] \mathrm{P}$ of $0.3 \mu \mathrm{g} / \mathrm{kg}^{*}$ day.

Olive oil stored in the bottle showed much higher PAH concentrations than the water, which is expected due to the general lipophilicity of PAHs (Table 1). Most PAHs showed a concentration increase over time, and olive oil stored in the bitumen-coated water bottle for 2 months showed high concentrations of in particular fluorene $(140 \mu \mathrm{g} / \mathrm{kg})$, phenanthrene $(80 \mu \mathrm{g} / \mathrm{kg})$, pyrene $(71 \mu \mathrm{g} / \mathrm{kg})$, and naphthalene $(67 \mu \mathrm{g} / \mathrm{kg})$ (Table 1). Although olives were not cultivated in California until the eighteenth century [75], these results suggest that fatty foods such as fish, shellfish, and marine mammals could have absorbed substantial amounts of PAHs from being in contact with bitumen used to e.g. coat baskets, repair fractured soapstone bowls, or glue mortar-basket hoppers [53].

Native Californians may furthermore have been exposed to PAHs by consuming marine animals from the Santa Barbara Channel, which is contaminated with PAHs from the submarine oil seeps. PAH concentrations in the Channel range from 0.6 to $28 \mu \mathrm{g} / \mathrm{L}$ in sediments from areas of active seepage $[67,76]$. Bile naphthalene levels were between 59 and $111 \mu \mathrm{g} / \mathrm{g}$ in rainbow surfperch (Hypsurus caryi) [49] and between 5 and $20 \mu \mathrm{g} / \mathrm{g}$ in Pacific sanddab (Citharichthys sordidus) [77] caught in these waters. For California sea otters from this region the liver naphthalene levels were less than $1 \mu \mathrm{g} / \mathrm{g}$ [78], i.e. lower than in the fish, which is reasonable given that mammals have more efficient $\mathrm{PAH}$ degradation mechanisms than fish. As whole-body $\mathrm{PAH}$ concentrations are lower than in liver and bile, consumption of e.g. $500 \mathrm{~g} /$ day [30] of contaminated fish/otter would result in a naphthalene intake well below EPA's RfD value of $20 \mu \mathrm{g} / \mathrm{kg}$ body weight per day [43].

In summary, non-negligible PAH levels, somewhat higher than those in cigarette smoke, were present in the fumes from the melting bitumen/pitch (yop) mixture. Fluoranthene was here the main toxicant. These results suggest that production of bitumen-coated objects such as water bottles and canoes could have been a source of harmful PAH exposure for prehistoric California Indians. Very small amounts of PAHs were 
found in water stored for 2 months in a bitumen-coated water bottle, indicating such water was safe to drink. Much higher PAH concentrations were observed in olive oil stored in the vessels, suggesting that harmful PAH exposure could have originated from fatty foods that had been in contact with bitumen-containing food processing items. Fatty fishes from the Santa Barbara Channel are contaminated with PAHs from submarine oil seeps, but consumption of such fish yields PAH intakes at tolerable levels. As PAHs typically are more toxic in mixtures due to synergistic effects [79], and as PAHs are especially harmful during the early developmental stages of life (i.e. prenatal and childhood) [11, 70, 80-82], further research and risk assessments in this area would benefit from the inclusion of age-specific information and adjustment factors.

From an archaeo-technology point of view, it is interesting that yop and malak were both found to be suitable materials for water-bottle coating, while pure woqo was not. One implication of this finding is that the prehistoric Channel Islanders, who only had local access to malak washing up on the shores, were self-sufficient with respect to water bottle manufacture. Trade of woqo from the mainland to the Islands is however well documented in ethnographic literature [63, 65], indicating that for certain uses the harder woqo was superior to the softer malak. It can also be noted that boiling a combination of bitumen and wood pitch to a mixture with suitable working properties is a practice described by the sixteenth century German scholar Agricola in De Re Metallica, his famous treatise on mining and metallurgy in mediaeval Saxony [83]. Apparently many cultures using bitumen as a crafting material discovered the advantages of this mixture. Thus, the $\mathrm{PAH}$ exposure data reported here are likely relevant also for crafts people from other cultures preparing similar mixtures, even though the exposure levels for specific PAHs likely vary with the bitumen/pitch ratio.

\section{Conclusions}

For ancient California Indians, water stored in bitumencoated water bottles was not a significant source of PAH exposure, but production of such bottles could have resulted in harmful airborne PAH exposure. Consumption of PAH-contaminated fish resulted in $\mathrm{PAH}$ exposure at tolerable levels. Thus, sub-lethal PAH exposure remains a possible factor in the health decline over time previously observed among the prehistoric coastal Chumash [31], but further research should emphasize the increased sensitivity to PAH exposure during prenatal and childhood stages. Studies that combine experimental archaeology with toxicology are few but valuable, as they may expand temporal perspectives in human toxicology and epidemiology, and can provide a broader evolutionary context for risk assessment in the present and future.

\section{Additional file}

Additional file 1: Table S1. Properties of the 16 priority PAHs. Figure S1. Photos of water bottle manufacture. Figure S2. Photos of bitumen processing. Figure $\mathbf{S 3}$. Photos of water bottle manufacture and experiments. (PDF $2437 \mathrm{~kb})$

\section{Abbreviations \\ B[a]P PEQ: benzo[a]pyrene potency equivalence; EPA: US Environmental Protection Agency; GC/MS: Gas chromatography/mass spectrometry; IRIS: Integrated risk information system; PAH: Polycyclic aromatic hydrocarbon; PUF: Poly-urethane foam; RfC: Inhalation reference concentration; RfD: Oral reference dose; RPF: Relative potency factor; TEF: Toxic equivalency factor}

\section{Acknowledgments \\ Kaitlin Brown provided mainland quarry bitumen (wogo) from Goleta, CA, and Lisa Thomas provided float asphaltum (malak) from San Nicolas Island, CA, for PAH analysis and water bottle construction. Nicolas Radtkey provided photo and video documentation of the water bottle manufacturing. Alex Izzarelli and Richard Odland provided the Juncus sp. rushes for the construction of the woven basketry water bottle framework. Ted Bowie provided advice for the PAH sampling, and Roger Westerholm helped with the PAH analysis. The manuscript was improved by the comments and suggestions of two external reviewers.}

\section{Funding}

None.

Availability of data and materials

All data generated and analyzed during this study are included in this manuscript and in the additional file 1.

\section{Authors' contributions}

$\mathrm{KS}, \mathrm{SBS}$, and SW conceived the project idea. KS replicated water bottles using ethnographic materials, and also conducted the PAH air experiments. CW, $T A$, and SW conducted the water/olive oil experiments and analyzed all PAH data. KS, SBS, and SW wrote the manuscript. All authors read and approved the final manuscript.

\section{Competing interests}

The authors declare that they have no competing interests.

Consent for publication

Not applicable.

Ethics approval and consent to participate

Not applicable.

\section{Publisher's Note}

Springer Nature remains neutral with regard to jurisdictional claims in published maps and institutional affiliations.

\section{Author details}

${ }^{1}$ Department of Anthropology, National Museum of Natural History, Smithsonian Institution, Washington, DC, USA. ${ }^{2}$ Center for Experimental Archaeology at Davis (CEAD), Department of Anthropology, University of California, Davis, California, USA. ${ }^{3}$ Department of Biochemistry and Biophysics, Stockholm University, S-106 91 Stockholm, Sweden. ${ }^{4}$ Department of Analytical Chemistry, Stockholm University, Stockholm, Sweden. ${ }^{5}$ UCLA/Getty Conservation Programme, Cotsen Institute of Archaeology, UCLA, Los Angeles, California, USA.

Received: 15 December 2016 Accepted: 17 May 2017

Published online: 23 June 2017

\section{References}

1. Eisler R. Polycyclic aromatic hydrocarbons. Handbook of chemical risk assessment. 2000;2:1343-411. 
2. Zhang Y, Tao S, Shen H, Ma J. Inhalation exposure to ambient polycyclic aromatic hydrocarbons and lung cancer risk of Chinese population. Proc Natl Acad Sci U S A. 2009;106(50):21063-7.

3. Shen H, Tao S, Liu J, Huang $Y$, Chen $H$, Li W, et al. Global lung cancer risk from $\mathrm{PAH}$ exposure highly depends on emission sources and individual susceptibility. Sci Rep. 2014;4:6561.

4. Boström C-E, Gerde P, Hanberg A, Jernström B, Johansson C, Kyrklund T, et al. Cancer risk assessment, indicators, and guidelines for polycyclic aromatic hydrocarbons in the ambient air. Environ Health Perspect. 2002; 110(Suppl 3):451-88.

5. Li T, Molenti A, Latkovich P, Castellani W, Baybutt RC. Vitamin a depletion induced by cigarette smoke is associated with the development of emphysema in rats. J Nutr. 2003;133:2629-34.

6. Mastrangelo G, Fadda E, Marzia V. Polycyclic aromatic hydrocarbons and cancer in man. Environ Health Perspect. 1996;104:1166-70.

7. Westerholm R, Alsberg T, Frommelin $\AA$, Strandell M, Rannug U, Winquist L, et al. Effect of fuel polycyclic aromatic hydrocarbon content on the Emissions of polycyclic aromatic hydrocarbons and other mutagenic substances from a gasoline-fueled automobile. Environ Sci Technol. 1988;22(8):925-30.

8. Westerholm R, Christensen A, Törnqvist M, Ehrenberg L, Rannug U, Sjögren M, et al. A comparison of exhaust Emissions from Swedish environmental classified diesel fuel (MK1) and European program on Emissions, fuels and engine technologies (EPEFE) reference fuel: a chemical and biological characterisation, with viewpoints on cancer risk. Environ Sci Technol. 2001;35:1748-54.

9. Choi H, Jedrychowski W, Spengler J, Camann DE, Whyatt RM, Rauh V, et al. International studies of prenatal exposure to polycyclic aromatic hydrocarbons and fetal growth. Environ Health Perspect. 2006;114(11):1744-50.

10. Choi $H$, Wang $L$, Lin $X$, Spengler JD, Perera FP. Fetal window of vulnerability to airborne polycyclic aromatic hydrocarbons on proportional intrauterine growth restriction. PLoS One. 2012;7(4):e35464.

11. Perera FP, Rauh V, Tsai W-Y, Kinney P, Camann D, Barr D, et al. Effects of transplacental exposure to environmental pollutants on birth outcomes in a multiethnic population. Environ Health Perspect. 2003;111(2):201.

12. Polanska K, Hanke W, Sobala W, Brzeznicki S, Ligocka D. Exposure to polycyclic aromatic hydrocarbons and newborn biometric indicators. Int J Occup Med Environ Health. 2010;23(4):339-46.

13. Somers CM, Yauk CL, White PA, Parfett CL, Quinn JS. Air pollution induces heritable DNA mutations. Proc Natl Acad Sci U S A. 2002;99(25):15904-7.

14. Hubbard TD, Murray IA, Bisson WH, Sullivan AP, Sebastian A, Perry GH, et al. Divergent ah receptor Ligand selectivity during Hominin evolution. Mol Biol Evol. 2016;33(10):2648-58.

15. Srogi K. Monitoring of environmental exposure to polycyclic aromatic hydrocarbons: a review. Environ Chem Lett. 2007;5(4):169-95.

16. Li Z, Commodore A, Hartinger S, Lewin M, Sjodin A, Pittman E, et al. Biomonitoring human exposure to household air pollution and association with self-reported health symptoms - a stove intervention study in Peru. Environ Int. 2016:97:195-203.

17. Sarigiannis D, Karakitsios SP, Zikopoulos D, Nikolaki S, Kermenidou M. Lung cancer risk from PAHs emitted from biomass combustion. Environ Res. 2015; 137:147-56.

18. Aveling EM, Heron C. Chewing tar in the early Holocene: an archaeological and ethnographic evaluation. Antiquity. 1999;73:579-84.

19. Connan J. Use and trade of bitumen in antiquity and prehistory: molecular archaeology reveals secrets of past civilizations. Philos Trans Royal Soc Lond Biol Sci. 1999;354:33-50.

20. Connan J, Nieuwenhuyse OP, Van As A, Jacobs L. Bitumen in early ceramic art. Archaeometry. 2004;46(1):115-24.

21. Harrell JA, Lewan MD. Sources of mummy bitumen in ancient Egypt and Palestine. Archaeometry. 2002;44:285-93.

22. Wendt CJ, Lu S-T. Sourcing archaeological bitumen in the Olmec region. J Archaeol Sci. 2006;33:89-97.

23. Schwartz M, Hollander D. The Uruk expansion as dynamic process: a reconstruction of Middle to late Uruk exchange patterns from bulk stable isotope analyses of bitumen artifacts. J Archaeol Sci Rep. 2016;7:884-99.

24. Boëda E, Bonilauri S, Connan J, Jarvie D, Mercier N, Tobey M, H. V, H. A-S. New Evidence for Significant Use of Bitumen in Middle Palaeolithic Technical Systems at Umm el Tlel (Syria) around 70,000 BP. Paléorient 2008;34(2):67-83.

25. Danion M, Deschamps MH, Thomas-Guyon H, Bado-Nilles A, Le Floch S, Quentel C, et al. Effect of an experimental oil spill on vertebral bone tissue quality in European sea bass (Dicentrarchus labrax L.). Ecotoxicol Environ Saf. 2011;74(7):1888-95.
26. Incardona JP, Collier TK, Scholz NL. Defects in cardiac function precede morphological abnormalities in fish embryos exposed to polycyclic aromatic hydrocarbons. Toxicol Appl Pharmacol. 2004;196(2):191-205.

27. Barry PSI, Mossman DB. Lead concentrations in human tissues. Br J Ind Med. 1970;27(4):339-51.

28. Li Z, Romanoff L, Bartell S, Pittman EN, Trinidad DA, McClean M, et al. Excretion profiles and half-lives of ten urinary polycyclic aromatic hydrocarbon metabolites after dietary exposure. Chem Res Toxicol. 2012;25(7):1452-61.

29. Forsberg ND, Stone D, Harding A, Harper B, Harris S, Matzke MM, et al. Effect of native American fish smoking methods on dietary exposure to polycyclic aromatic hydrocarbons and possible risks to human health. J Agric Food Chem. 2012;60(27):6899-906.

30. Harris SG, Harper BL. A native American exposure scenario. Risk Anal. 1997; 17(6):789-95.

31. Wärmländer SK, Sholts SB, Erlandson JM, Gjerdrum T, Westerholm R. Could the health decline of prehistoric California indians be related to exposure to polycyclic aromatic hydrocarbons (PAHs) from natural bitumen? Environ Health Perspect. 2011;119(9):1203.

32. Lambert PM. Temporal variation in the health status of prehistoric populations of Santa Cruz Island. M.A. Thesis. Santa Barbara: University of California; 1989.

33. Lambert PM. Health in prehistoric populations of the Santa Barbara Channel islands. Am Antiq. 1993;58(3):509-22.

34. Lambert PM. War and peace on the western front: a study of violent conflict and its correlates in prehistoric hunter-gatherer societies of coastal southern California. Doctoral dissertation. Santa Barbara: University of California; 1994.

35. Lambert PM. Health in prehistoric populations of the Santa Barbara Channel islands. In: Raab ML, Jones TL, editors. Prehistoric California: archaeology and the myth of paradise. Salt Lake City: The University of Utah Press; 2004. p. 99-106.

36. Walker PL. Porotic hyperostosis in a marine-dependent California Indian population. Am J Phys Anthropol. 1986;69(3):345-54.

37. Walker PL. Enamel hypoplasia during 5000 years of southern California prehistory. Editors. Health and disease in the prehistoric southwest II. Albuquerque: University of Mexico Press; 1993.

38. Walker PL, Erlandson JM. Dental evidence for prehistoric dietary change on the northern Channel Islands. California Am Antiquity. 1986:51:375-83.

39. Walker PL, Lambert PM. Skeletal evidence for stress during a period of cultural change in prehistoric California. In: Capasso L, editor. Advances in paleopathology, journal of Paleopathology: monographic publication no 1. Chieti, Italy: Marino Solfanelli; 1989. p. 207-12.

40. Walker PL, Thornton R. Health, nutrition, and demographic change in native California. In: Steckel RH, Rose JC, editors. The backbone of history Cambridge: Cambridge University Press; 2002. p. 506-23.

41. Athanasiou M, Tsantali C, Trachana M, Hatziioannides C. Hemolytic anemia in a female newborninfant whose mother inhaled naphthalene before delivery. J Pediatr. 1997;130(4):680-1.

42. ECB. Summary Risk Assessment Report: Naphthalene, CAS No: 91-20-3, EINECS No: 202-049-5. Ispra: European Chemicals Bureau; 2003. https:// echa.europa.eu/documents/10162/e1dc4188-c5b1-444d-8ff1-71002ebe12d6.

43. EPA. Integrated Risk Information System (IRIS) Chemical Assessment Summary, Napthalene; CASRN 91-20-3. Washington, DC: US EPA; 1998.

44. US EPA. Napthalene: Hazard Summary. Washington D.C.: United States Environmental Protection Agency; 2000. https://www.epa.gov/sites/ production/files/2016-09/documents/naphthalene.pdf.

45. Perera FP, Whyatt RM, Jedrychowski W, Rauh V, Manchester D, Santella RM, et al. A study of the effects of environmental polycyclic aromatic hydrocarbons on birth outcomes in Poland. Am J Epidemiol. 1998;147(3):309-14.

46. Walker PL, Bathhurst RR, Richman R, Gjerdrum T, Andrushko VA. The causes of porotic hyperostosis and cribra orbitalia: a reappraisal of the irondeficiency-anemia hypothesis. Am J Phys Anthropol. 2009;139:109-25.

47. Zarina G, Sholts SB, Tichinin A, Rudovica V, Viksna A, Engizere A, et al. Cribra orbitalia as a potential indicator of childhood stress: evidence from paleopathology, stable C, N, and O isotopes, and trace element concentrations in children from a 17th-18th century cemetery in Jekabpils, Latvia. J Trace Elem Med Biol. 2016;38:131-7.

48. Davis PH, Schultz TW, Spies RB. Toxicity of Santa Barbara seep oil to starfish embryos: part 2-the growth bioassay. Marine Environ Res. 1981;5(4):287-94.

49. Spies RB, Stegeman JJ, Hinton DE, Woodin B, Smolowitz R, Okihiro M, et al. Biomarkers of hydrocarbon exposure and sublethal effects in embiotocid fishes from a natural petroleum seep in the Santa Barbara Channel. Aquat Toxicol. 1996;34:195-219. 
50. Brown KM, Connan J, Poister NW, Vellanoweth RL, Zumberge J, Engel MH. Sourcing archaeological asphaltum (bitumen) from the California Channel islands to submarine seeps. J Archaeol Sci. 2014;43:66-76.

51. Brown KM, Kendig WE, Vellanoweth RL, Connan J. Poster presentation: What is mixed in a mixing dish? An experimental and chemical analysis of asphaltum filled abalone dishes on san Nicolas Island. Berkeley: Society for California Archaeology Annual Meeting; 2013.

52. Brown KM, Vellanoweth RL. Linking the artifact to the activity: tarring pebble classification and use of Asphaltum on san Nicolas Island. Alta California California Archaeology. 2014;6(1):1-22.

53. Hodgson SF. California Indians, artisans of oil. Sacramento: California Department of Conservation, Divison of Oil, Gas, and Geothermal Resources; 2004.

54. Fauvelle M, Smith EM, Brown SH, Des Lauriers MR. Asphaltum hafting and projectile point durability: an experimental comparison of three hafting methods. J Archaeol Sci. 2012;39(8):2802-9.

55. Vellanoweth RL, Lambright MR, Erlandson JM, Rick TC. Early new world maritime technologies: sea grass cordage, shell beads, and a bone tool from cave of the chimneys, San Miguel Island, California. USA J Archaeological Sci. 2003;30(9):1161-73.

56. Braje TJ, Erlandson JM, Timbrook J. An asphaltum coiled basket impression, tarring pebbles, and Middle Holocene water bottles from San Miguel Island, California. J Calif Gt Basin Anthropol. 2005;25(2):207-13.

57. Gamble L. Archaeological evidence for the origin of the plank canoe in North America. Am Antiq. 2002;67(2):301-15.

58. Sholts SB, Clement AF, Wärmländer SKTS. Brief communication: Additional cases of maxillary canine-first premolar transposition in several prehistoric skeletal assemblages from the Santa Barbara Channel Islands of California. Am J Phys Anthropol. 2010;In press.

59. Fauvelle M. Acorns, Asphaltum, and asymmetrical exchange: invisible exports and the political economy of the Santa Barbara Channel. Am Antiq. 2014;79(3):573-5.

60. Mohr A, Sample LL. Twined water bottles of the Cuyama area, southern California. Am Antiq. 1955:345-54.

61. Timbrook J. Chumash ethnobotany: plant knowledge among the Chumash people of southern California. Santa Barbara: Heyday Books; 2007.

62. Nidever G. The life and adventures of a pioneer of California since 1834. Manuscript, University of California Bancroft Library, Berkeley, CA. 1878.

63. Hudson T, Blackburn TC. The material culture of the Chumash interaction sphere. Volume V: Maufacturing process, metrology, and trade. Santa Barbara: Ballena Press; 1986.

64. Gutman TE. The use of asphaltum sourcing in archaeology. J New World Archaeol. 1979;3(2):32-43.

65. Hudson T, Timbrook J, Rempe M (eds). Tomol: Chumash watercraft as described in the ethnographic notes of John P. Harrington. Santa Barbara: Ballena Press; 1978.

66. Brown KM. A functional analysis of asphaltum utilization on san Nicolas Island: acquisition, processing, and application at the Tule Creek site (CASNI-25). California: San Nicolas Island; 2013.

67. Stuermer DH, Spies RB, Davis PH, Ng DJ, Morris CJ, Neal S. The hydrocarbons in the isla vista marine seep environment. Mar Chem. 1982;11:413-26.

68. Andersson JT, Achten C. Time to say goodbye to the 16 EPA PAHs? Toward an up-to-date use of PACs for environmental purposes. Polycycl Aromat Compd. 2015;35(2-4):330-54.

69. WHO. WHO guidelines for indoor air quality: selected pollutants. Copenhagen: World Health Organization Regional Office for Europe; 2010. http://www.euro.who.int/_data/assets/pdf_file/0009/128169/e94535.pdf.

70. Minnesota Department of Health (MDH). Guidance for Evaluating the Cancer Potency of Polycyclic Aromatic Hydrocarbon (PAH) Mixtures in Environmental Samples. St. Paul: Minnesota Department of Health; 2016. http://www.health.state.mn.us/divs/eh/risk/guidance/pahguidance.pdf.

71. Jia C, Batterman S. A critical review of naphthalene sources and exposures relevant to indoor and outdoor air. Int J Environ Res Public Health. 2010; 7(7):2903-39.

72. U.S. EPA: IRIS Toxicological Review of Naphthalene (External Review Draft, Update). 2004.

73. Zurabashvili D, Parulava G, Gvishiani Z, Shanidze L, Garuchava M. The level of naphthalene and its derivatives in cigarette smoke. Georgian Med News. 2016;250:93-5

74. Winter JC. Tobacco use by native north americans - sacred smoke and silent killer. Norman, Oklahoma, USA: University of Oklahoma Press; 2000.
75. White JL. Diffusion of olive cultivation into California. Northridge, CA, USA: California State University, Northridge; 1975.

76. Stuermer DH, Spies RB, Davis PH. Toxicity of Santa Barbara seep oil to starfish embryos: part 1-hydrocarbon composition of test solutions and field samples. Marine Environ Res. 1981;5(4):275-86.

77. Gale RW, Tanner MJ, Love MS, Nishimoto MM, Schroeder DM. Open-File Report 2012-1248: Comparison of concentrations and profiles of polycyclic aromatic hydrocarbon metabolites in bile of fishes from offshore oil platforms and natural reefs along the California coast. Reston: US Geological Survey; 2012. https://pubs.er.usgs.gov/publication/ofr20121248.

78. Kannan K, Perrotta E. Polycyclic aromatic hydrocarbons (PAHs) in livers of California sea otters. Chemosphere. 2008;71(4):649-55.

79. Rotkin-Ellman M, Wong KK, Solomon GM. Seafood contamination after the BP gulf oil spill and risks to vulnerable populations: a critique of the FDA risk assessment. Environ Health Perspect. 2012;120(2):157-1161.

80. Landrigan PJ, Kimmel CA, Correa A, Eskenazi B. Children's health and the environment: public health issues and challenges for risk assessment. Environ Health Perspect. 2004;112(2):257-65.

81. Ghosh JK, Wilhelm M, Su J, Goldberg D, Cockburn M, Jerrett M, et al. Assessing the influence of traffic-related air pollution on risk of term low birth weight on the basis of land-use-based regression models and measures of air toxics. Am J Epidemiol. 2012;175(12):1262-74.

82. Edwards SC, Jedrychowski W, Butscher M, Camann D, Kieltyka A, Mroz E, et al. Prenatal exposure to airborne polycyclic aromatic hydrocarbons and children's intelligence at 5 years of age in a prospective cohort study in Poland. Environ Health Perspect. 2010;118(9):1326-31.

83. Agricola G. De Re Metallica (1556). Translated to English by Herbert and Lou Hoover. New York City: Dover Publications, Inc.; 1950.

\section{Submit your next manuscript to BioMed Central and we will help you at every step:}

- We accept pre-submission inquiries

- Our selector tool helps you to find the most relevant journal

- We provide round the clock customer support

- Convenient online submission

- Thorough peer review

- Inclusion in PubMed and all major indexing services

- Maximum visibility for your research

Submit your manuscript at www.biomedcentral.com/submit
Biomed Central 